\title{
Plasma-Assisted Catalytic Reduction of NOx
}

B.M Penetrante, R.M. Brusasco, B.T. Merritt, W.J. Pitz, G.E. Vogtlin, M.C. Kung, H.H. Kung, C.Z. Wan and K.E. Voss

This paper was prepared for submittal to the

1998 Society of Automotive Engineers

Fall Fuels and Lubricants Meeting

San Francisco, $\mathrm{CA}$

October 19-22, 1998

August 24, 1998

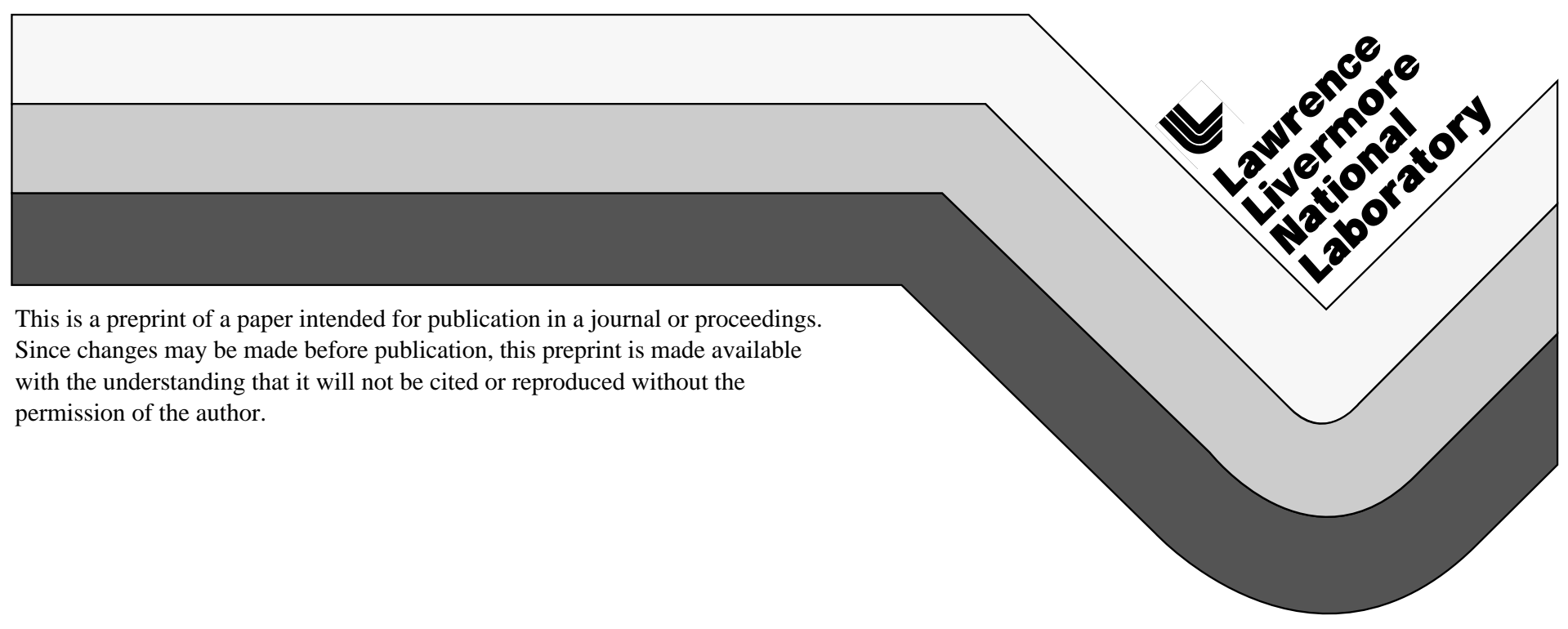




\section{DISCLAIMER}

This document was prepared as an account of work sponsored by an agency of the United States Government. Neither the United States Government nor the University of California nor any of their employees, makes any warranty, express or implied, or assumes any legal liability or responsibility for the accuracy, completeness, or usefulness of any information, apparatus, product, or process

disclosed, or represents that its use would not infringe privately owned rights. Reference herein to any specific commercial product, process, or service by trade name, trademark, manufacturer, or otherwise, does not necessarily constitute or imply its endorsement, recommendation, or favoring by the United States Government or the University of California. The views and opinions of authors expressed herein do not necessarily state or reflect those of the United States Government or the University of California, and shall not be used for advertising or product endorsement purposes. 


\title{
Plasma-Assisted Catalytic Reduction of $\mathrm{NO}_{\mathrm{x}}$
}

\author{
B. M. Penetrante, R. M. Brusasco, B. T. Merritt, W. J. Pitz and G. E. Vogtlin \\ Lawrence Livermore National Laboratory \\ M. C. Kung and H. H. Kung \\ Center for Catalysis and Surface Science, Northwestern University \\ C. Z. Wan and K. E. Voss \\ Engelhard Corporation
}

Copyright () 1998 Society of Automotive Engineers, Inc.

\begin{abstract}
Many studies suggest that lean- $\mathrm{NO}_{\mathrm{X}} \mathrm{SCR}$ proceeds via oxidation of $\mathrm{NO}$ to $\mathrm{NO}_{2}$ by oxygen, followed by the reaction of the $\mathrm{NO}_{2}$ with hydrocarbons. On catalysts that are not very effective in catalyzing the equilibration of $\mathrm{NO}+\mathrm{O}_{2}$ and $\mathrm{NO}_{2}$, the rate of $\mathrm{N}_{2}$ formation is substantially higher when the input $\mathrm{NO}_{\mathrm{x}}$ is $\mathrm{NO}_{2}$ instead of NO. The apparent bifunctional mechanism in the SCR of $\mathrm{NO}_{\mathrm{X}}$ has prompted the use of mechanically mixed catalyst components, in which one component is used to accelerate the oxidation of $\mathrm{NO}$ to $\mathrm{NO}_{2}$, and another component catalyzes the reaction between $\mathrm{NO}_{2}$ and the hydrocarbon. Catalysts that previously were regarded as inactive for $\mathrm{NO}_{\mathrm{x}}$ reduction could therefore become efficient when mixed with an oxidation catalyst. Preconverting $\mathrm{NO}$ to $\mathrm{NO}_{2}$ opens the opportunity for a wider range of SCR catalysts and perhaps improves the durability of these catalysts. This paper describes the use of a non-thermal plasma as an efficient means for selective partial oxidation of $\mathrm{NO}$ to $\mathrm{NO}_{2}$. When combined with some types of SCR catalyst, the plasma can greatly enhance the $\mathrm{NO}_{\mathrm{X}}$ reduction and eliminate some of the deficiencies encountered in an entirely catalyst-based approach.
\end{abstract}

\section{INTRODUCTION}

Lean-burn engines have attracted considerable attention because of their high fuel efficiency and lower emission of carbon dioxide. These engines operate under net oxidizing conditions, thus rendering conventional threeway catalysts ineffective for controlling the $\mathrm{NO}_{\mathrm{X}}$ emission. The $\mathrm{NO}_{\mathrm{X}}$ in engine exhaust is composed primarily of NO; consequently, aftertreament schemes have focused a great deal on the reduction of NO. Selective catalytic reduction (SCR) by hydrocarbons [12] is one of the leading catalytic aftertreatment technologies for the reduction of $\mathrm{NO}_{\mathrm{X}}$ in lean-burn engine exhaust. In lean- $\mathrm{NO}_{\mathrm{X}} \mathrm{SCR}$, the oxidation of $\mathrm{NO}$ to $\mathrm{NO}_{2}$ serves an important role in enhancing the efficiency for reduction of $\mathrm{NO}_{x}$ to $\mathrm{N}_{2}$.

This paper describes the use of a non-thermal plasma as an efficient means for selective partial oxidation of $\mathrm{NO}$ to $\mathrm{NO}_{2}$. A short background on the significance of $\mathrm{NO}_{2}$ in lean- $\mathrm{NO}_{\mathrm{x}} \mathrm{SCR}$ is given in Section II. The mechanism of plasma oxidation of $\mathrm{NO}$ to $\mathrm{NO}_{2}$ is described in Section III. It is discussed why the plasma, by itself, cannot lead to the chemical reduction of $\mathrm{NO}_{X}$ to $\mathrm{N}_{2}$ in lean-burn gas mixtures. The role of hydrocarbons in the plasma oxidation process is explained. In combination with some types of SCR catalyst, the plasma can greatly enhance the $\mathrm{NO}_{\mathrm{X}}$ reduction. The plasma-assisted catalytic reduction process is described in Section IV. An example is then presented to demonstrate the improvement in $\mathrm{NO}_{x}$ reduction efficiency that can be accomplished by combining a representative SCR catalyst with a plasma.

\section{SIGNIFICANCE OF $\mathrm{NO}_{2}$ IN LEAN-NO $\mathrm{XCR}$}

Many studies suggest that lean- $\mathrm{NO}_{\mathrm{X}} \mathrm{SCR}$ proceeds via oxidation of $\mathrm{NO}$ to $\mathrm{NO}_{2}$ by oxygen, followed by the reaction of the $\mathrm{NO}_{2}$ with hydrocarbons [3-13]. On catalysts that are not very effective in catalyzing the equilibration of $\mathrm{NO}+\mathrm{O}_{2}$ and $\mathrm{NO}_{2}$, the rate of $\mathrm{N}_{2}$ formation is substantially higher when the input $\mathrm{NO}_{X}$ is $\mathrm{NO}_{2}$ instead of $\mathrm{NO}$. This has been observed on $\mathrm{Na}$ ZSM-5 [9], Ce-ZSM-5 [9], $\gamma-\mathrm{Al}_{2} \mathrm{O}_{3}$ [3], H-ZSM-5 [3], $\mathrm{ZrO}_{2}$ [14], and $\mathrm{Ga}_{2} \mathrm{O}_{3}$ [14]. It has also been observed that Group II metal oxides in general are much more effective in the SCR of $\mathrm{NO}_{2}$ compared to $\mathrm{NO}$ [15].

The apparent bifunctional mechanism in the SCR of $\mathrm{NO}_{\mathrm{x}}$ has prompted the use of mechanically mixed catalyst components, in which one component (for example, $\mathrm{Mn}_{2} \mathrm{O}_{3}$ or $\mathrm{Mn}_{3} \mathrm{O}_{4}$ ) is used to accelerate the oxidation of $\mathrm{NO}$ to $\mathrm{NO}_{2}$ and another component (for example, Sn- 
ZSM-5 or $\operatorname{In} / \mathrm{Al}_{2} \mathrm{O}_{3}$ ) catalyzes the reaction between $\mathrm{NO}_{2}$ and the hydrocarbon [16-18]. Catalysts that previously were regarded as inactive for $\mathrm{NO}_{\mathrm{x}}$ reduction could therefore become efficient when mixed with an oxidation catalyst.

The apparent role of $\mathrm{NO}_{2}$ in the SCR of $\mathrm{NO}_{x}$ has also prompted the use of a multi-stage system in which an oxidation catalyst (for example, Pt-MFI zeolite) is used upstream of a reduction catalyst (for example, In-MFI or Zn-MFI zeolite) [19-20]. This latter method works fine particularly for systems that require hydrocarbon addition; the hydrocarbon can be injected between the oxidation catalyst and the reduction catalyst. For a leanburn exhaust that already has a significant amount of hydrocarbons, the oxidation catalyst for $\mathrm{NO}$ is also active for the oxidation of the hydrocarbon; this results in a decrease in the efficiency of the hydrocarbon reductant.

It has been pointed out by Bethke et al. [21] and Chajar et al. [22] that the formation of gas phase $\mathrm{NO}_{2}$ does not necessarily precede the formation of $\mathrm{N}_{2}$. On catalysts such as $\mathrm{Al}_{2} \mathrm{O}_{3}$ that are less active in the oxidation of $\mathrm{NO}$ to $\mathrm{NO}_{2}$, Bethke et al. [21] suggests that the $\mathrm{N}_{2}$ production is higher using $\mathrm{NO}_{2}$ than $\mathrm{NO}$ because of the higher surface coverage of adsorbed $\mathrm{NO}_{2}$. The adsorbed $\mathrm{NO}_{2}$ forms an adsorbed oxidized $\mathrm{N}$-containing hydrocarbon intermediate. The reaction of this intermediate with $\mathrm{NO}$ is then the principal route to the production of $\mathrm{N}_{2}$. For catalysts that deactivate due to coking, $\mathrm{NO}_{2}$ helps maintain the activity by removing the surface carbonaceous species, resulting in an impression that $\mathrm{NO}_{2}$ is a reagent for $\mathrm{N}_{2}$ production. In any case, it is apparent that preconverting $\mathrm{NO}$ to $\mathrm{NO}_{2}$ opens the opportunity for a wider range of SCR catalysts and perhaps improves the durability of these catalysts.

\section{PLASMA PROCESS}

A non-thermal plasma [23-25] is a very effective means for oxidizing $\mathrm{NO}$ to $\mathrm{NO}_{2}$ in the gas-phase under leanburn engine exhaust conditions. The use of a plasma can improve the $\mathrm{NO}_{x}$ reduction efficiency and eliminate some of the deficiencies encountered in an entirely catalyst-based approach. The plasma can oxidize NO to $\mathrm{NO}_{2}$ without depleting the amount of hydrocarbons available for SCR of $\mathrm{NO}_{2}$ to $\mathrm{N}_{2}$. The function of the SCR catalyst can thus be greatly simplified by focusing on the reduction of $\mathrm{NO}_{2}$ by the hydrocarbon. Furthermore, the plasma can oxidize $\mathrm{NO}$ without oxidizing $\mathrm{SO}_{2}$, thus making the process tolerant to the sulfur content of the fuel.

Previous studies [26-28] have shown that all electrical discharge plasma reactors produce a plasma with an average electron kinetic energy of around 3-6 eV. The plasma chemistry in discharge plasma reactors is therefore very similar regardless of electrode structure or the way the voltage is delivered to the reactor.
TEST SETUP - The plasma reactor used in our study is a pulsed corona discharge reactor consisting of a metal wire inside a metal cylinder. The power supply is a magnetic pulse compression system that delivers up to $30 \mathrm{kV}$ output into $100 \mathrm{~ns}$ pulses at repetition rates up to the kilohertz range. The electrical energy deposition into the gas is determined by monitoring the electrical parameters associated with the discharge. To obtain pulse energies a digital oscilloscope records both the voltage and current profiles. We measure the total current which contains both the discharge current and the current associated with charging the capacitance of the reactor. A computer data acquisition system reads the voltage and current profiles and integrates the product of the voltage and discharge current over the pulse duration to yield the pulse energy. The determination of the power input to the gas takes into account the capacitor charging current correction. The power input to the plasma processor was varied by changing either the pulse energy or pulse repetition frequency.

Heater bands and thermocouples are used to provide active control of the plasma/catalyst processor temperature. The processor temperature can be adjusted from room temperature up to $500^{\circ} \mathrm{C}$. This has been used to investigate the operating temperature window of the process. The catalyst structures we have investigated in combination with the plasma consisted of either a pellet bed or a monolith.

A gas blending manifold is used to custom make gas streams consisting of $\mathrm{N}_{2}, \mathrm{O}_{2}, \mathrm{H}_{2} \mathrm{O}, \mathrm{CO}_{2}$, hydrocarbons and $\mathrm{NO}_{\mathrm{X}}$. These gases are metered through mass flow controllers which permitted exact control of the flow rate. After mixing in the manifold, the gas then passes through a temperature controlled heater which preheated the gas to the processor temperature. The use of custom-made gas mixtures is necessary for studying the effect of the gas composition on the gasphase plasma chemistry and the activity of the catalyst. The effect of various gas components on the process products and process efficiency can thus be studied.

The gas composition is monitored with a chemiluminescent $\mathrm{NO}_{x}$ analyzer and a Fourier Transform Infrared (FTIR) spectrometer. Because our gas samples contain water in some experiments, we heat the FTIR cell $\left(6-\mathrm{m}\right.$ path White cell) to $120^{\circ} \mathrm{C}$ to avoid condensation. In addition, we use a heated sample gas dilution and conditioning unit before the $\mathrm{NO}_{\mathrm{X}}$ analyzer.

The plasma processor is also connected to a generator set consisting of a Cummins B5.9 diesel engine. This enables us to test the process on a real diesel exhaust.

PLASMA WITHOUT HYDROCARBONS - In the plasma, oxidation is the dominant process for exhausts 
containing dilute concentrations of $\mathrm{NO}$ in mixtures of $\mathrm{N}_{2}$, $\mathrm{O}_{2}$ and $\mathrm{H}_{2} \mathrm{O}$, particularly when the $\mathrm{O}_{2}$ concentration is $5 \%$ or higher. The kinetic energy of the electrons is deposited primarily into the major gas components, $\mathrm{N}_{2}$ and $\mathrm{O}_{2}$. The most useful deposition of energy is associated with the production of $\mathrm{N}$ and $\mathrm{O}$ radicals through electron-impact dissociation:

$$
\begin{aligned}
& \mathrm{e}+\mathrm{N}_{2} \rightarrow \mathrm{e}+\mathrm{N}\left({ }^{4} \mathrm{~S}\right)+\mathrm{N}\left({ }^{4} \mathrm{~S},{ }^{2} \mathrm{D}\right) \\
& \mathrm{e}+\mathrm{O}_{2} \rightarrow \mathrm{e}+\mathrm{O}\left({ }^{3} \mathrm{P}\right)+\mathrm{O}\left({ }^{3} \mathrm{P},{ }^{1} \mathrm{D}\right)
\end{aligned}
$$

where $\mathrm{N}\left({ }^{4} \mathrm{~S}\right)$ and $\mathrm{N}\left({ }^{2} \mathrm{D}\right)$ are ground-state and metastable excited-state nitrogen atoms, respectively, and $O\left({ }^{3} P\right)$ (simply referred to as $O$ ) and $O\left({ }^{1} D\right)$ are ground-state and metastable excited-state oxygen atoms, respectively. The $N\left({ }^{4} S\right)$ is the only plasmaproduced species that could effectively lead to the chemical reduction of NO [24,29]:

$$
\mathrm{N}\left({ }^{4} \mathrm{~S}\right)+\mathrm{NO} \rightarrow \mathrm{N}_{2}+\mathrm{O}
$$

In the presence of $\mathrm{O}_{2}$, the oxidation pathway becomes dominant for two reasons:

(a) The dissociation energy of $\mathrm{O}_{2}$ is smaller than that of $\mathrm{N}_{2}$. For electrical discharge plasma reactors, the average electron kinetic energy is low, around 3-6 eV.[26-28] Under this condition the rate for dissociation of $\mathrm{O}_{2}$ is much higher compared to the dissociation of $\mathrm{N}_{2}$.[23-24] The dissociation of $\mathrm{O}_{2}$ will produce only oxidative radicals. The ground-state oxygen atom, $\mathrm{O}\left({ }^{3} \mathrm{P}\right)$, will convert $\mathrm{NO}$ to $\mathrm{NO}_{2}$ via

$$
\begin{aligned}
& \mathrm{O}\left({ }^{3} \mathrm{P}\right)+\mathrm{NO}+\mathrm{M} \rightarrow \mathrm{NO}_{2}+\mathrm{M} \\
& \mathrm{O}\left({ }^{3} \mathrm{P}\right)+\mathrm{O}_{2}+\mathrm{M} \rightarrow \mathrm{O}_{3}+\mathrm{M} \\
& \mathrm{O}_{3}+\mathrm{NO} \rightarrow \mathrm{NO}_{2}+\mathrm{O}_{2}
\end{aligned}
$$

The metastable oxygen atom, $O\left({ }^{1} D\right)$, will react with $\mathrm{H}_{2} \mathrm{O}$ to produce $\mathrm{OH}$ radicals:

$$
\mathrm{O}\left({ }^{1} \mathrm{D}\right)+\mathrm{H}_{2} \mathrm{O} \rightarrow 2 \mathrm{OH}
$$

The $\mathrm{OH}$ radicals will convert $\mathrm{NO}$ and $\mathrm{NO}_{2}$ to nitrous and nitric acid, respectively.

(b) High electron energies are required to optimize the production of $\mathrm{N}\left({ }^{4} \mathrm{~S}\right)$ by electron-impact dissociation of $\mathrm{N}_{2}$. Under conditions optimum for the dissociation of $\mathrm{N}_{2}$, a large number of excited nitrogen atoms, $\mathrm{N}\left({ }^{2} \mathrm{D}\right)$, is produced [30-31]. The $\mathrm{N}\left({ }^{2} \mathrm{D}\right)$ species can lead to undesired reactions in the presence of $\mathrm{O}_{2}$. Rather than reduce $\mathrm{NO}$, the $\mathrm{N}\left({ }^{2} \mathrm{D}\right)$ species would react with $\mathrm{O}_{2}$ to produce $\mathrm{NO}$ :

$$
\mathrm{N}\left({ }^{2} \mathrm{D}\right)+\mathrm{O}_{2} \rightarrow \mathrm{NO}+\mathrm{O}
$$

Because of the large rate constant [32] for reaction (7) and the large concentration of $\mathrm{O}_{2}$ relative to $\mathrm{NO}$, the $N\left({ }^{2} D\right)$ species preferentially reacts with $\mathrm{O}_{2}$ to produce NO. In a lean-burn exhaust, the production of $\mathrm{NO}$ by $N\left({ }^{2} \mathrm{D}\right)$ will counterbalance the reduction of $\mathrm{NO}$ by $\mathrm{N}\left({ }^{4} \mathrm{~S}\right)$, thus effectively leaving oxidation as the only pathway for NO conversion. The effect of $\mathrm{N}\left({ }^{2} \mathrm{D}\right)$ on the $\mathrm{NO}_{\mathrm{x}}$ conversion chemistry has been validated in comparison with experiments [24].

We examined the plasma processing of $100 \mathrm{ppm} \mathrm{NO}$ in a dry mixture of $10 \% \mathrm{O}_{2}$ and balance $\mathrm{N}_{2}$, without hydrocarbons. The purpose of this experiment was to determine the efficiency for plasma oxidation of NO to $\mathrm{NO}_{2}$ by the $\mathrm{O}$ radical. The $\mathrm{NO}_{x}$ concentrations for the cases at $100^{\circ} \mathrm{C}$ and $300^{\circ} \mathrm{C}$ are shown in Figures 1 (a) and $1(\mathrm{~b})$, respectively. They are plotted as a function of electrical energy density $(\mathrm{J} / \mathrm{L})$, which is the electrical power delivered to the plasma divided by the gas flow rate. The lines shown in the figures are fits to the experimental data points. For the $100^{\circ} \mathrm{C}$ case, about $60 \%$ of the $\mathrm{NO}$ are converted to $\mathrm{NO}_{2}$ at energy densities of $40 \mathrm{~J} / \mathrm{L}$ and above. For the $300^{\circ} \mathrm{C}$ case, the conversion of $\mathrm{NO}$ to $\mathrm{NO}_{2}$ is only around $20 \%$ even at the high energy densities.

For a given energy density input, the $\mathrm{NO}_{x}$ conversion chemistry in the plasma is accomplished in tens of milliseconds. The plasma reactions can therefore accommodate very high space velocities. The factors that determine the products of the plasma chemistry are the energy density input, gas composition and gas temperature. Under some conditions, if the radical production rate in the plasma is too high and the initial $\mathrm{NO}_{X}$ concentration is low, some of the radicals could end up forming $\mathrm{NO}_{\mathrm{X}}$.

The efficiency for oxidation of $\mathrm{NO}$ to $\mathrm{NO}_{2}$ drops as the temperature is increased. At high temperatures, the NO to $\mathrm{NO}_{2}$ oxidation reaction is counteracted by the reduction reaction:

$$
\mathrm{O}+\mathrm{NO}_{2} \rightarrow \mathrm{NO}+\mathrm{O}_{2}
$$

Because of reaction (8), the oxidation of $\mathrm{NO}$ by the $\mathrm{O}$ radical is not efficient at high temperatures. We will show in the next section that the NO oxidation efficiency in the plasma can improve dramatically in the presence of hydrocarbons.

PLASMA WITH HYDROCARBONS - We next examined the effect of hydrocarbons on the plasma processing of NO. Propene was used as a representative hydrocarbon. The dry gas mixture contained 500 ppm $\mathrm{NO}$ in $10 \% \mathrm{O}_{2}$ and balance $\mathrm{N}_{2}$. The purpose of this experiment was to determine how the hydrocarbon affects the plasma oxidation of $\mathrm{NO}$ to $\mathrm{NO}_{2}$. 

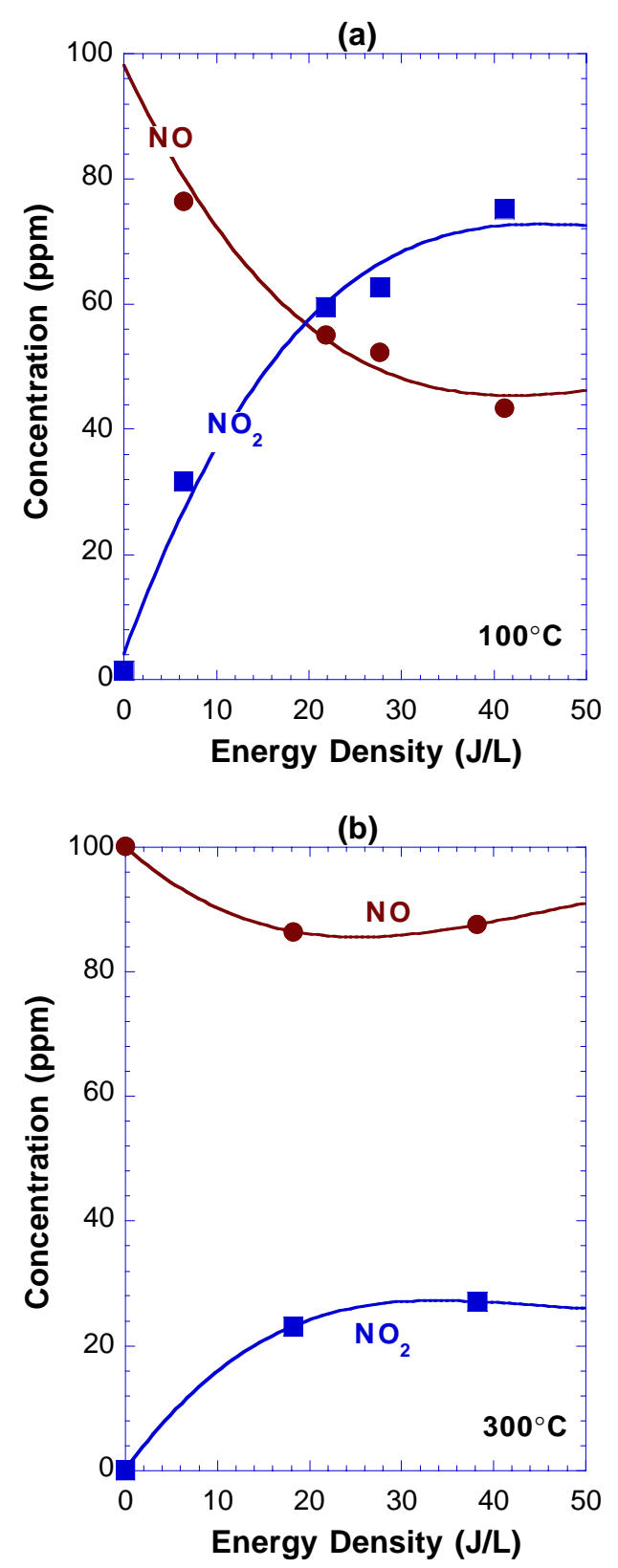

Figure 1. Effect of temperature on the plasma oxidation of $\mathrm{NO}$ in the absence of hydrocarbons. Plasma processing of $100 \mathrm{ppm} \mathrm{NO}$ in $10 \% \mathrm{O}_{2}$, balance $\mathrm{N}_{2}$, at (a) $100^{\circ} \mathrm{C}$ and (b) $300^{\circ} \mathrm{C}$.

The $\mathrm{NO}_{\mathrm{x}}$ concentrations for the cases without propene and with $1000 \mathrm{ppm}$ propene are shown in Figures 2(a) and 2 (b), respectively, for processing at $300^{\circ} \mathrm{C}$.

For the case without propene (Figure 2(a)), less than $20 \%$ of the $\mathrm{NO}$ is converted to $\mathrm{NO}_{2}$ even at the high energy densities. This is consistent with the previous observation shown in Figure 1(b).

The number of $\mathrm{NO}$ molecules converted to $\mathrm{NO}_{2}$ is determined by the number of $O$ radicals produced by the plasma, not by the initial NO concentration. The number
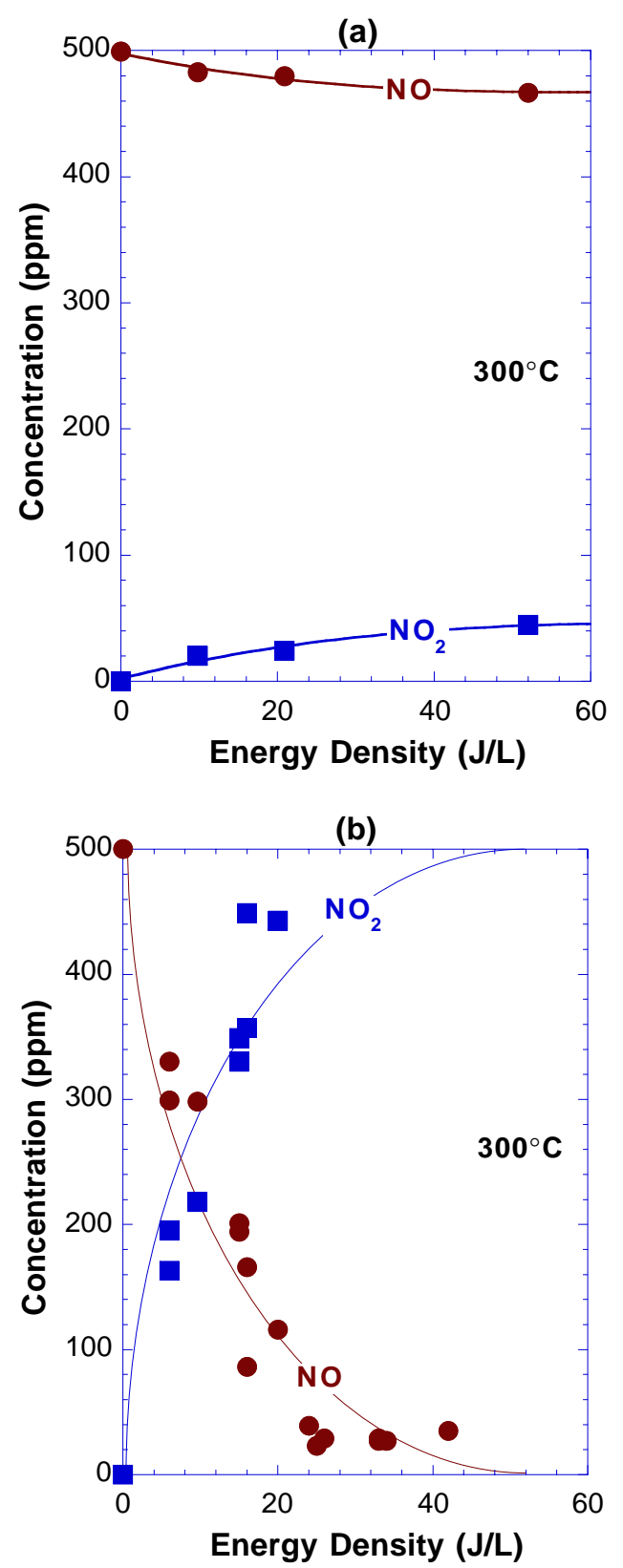

Figure 2. Effect of propene on the plasma oxidation of $\mathrm{NO}$ at $300^{\circ} \mathrm{C}$. Plasma processing of $500 \mathrm{ppm} \mathrm{NO}$ in $10 \%$ $\mathrm{O}_{2}$, balance $\mathrm{N}_{2}$, (a) without propene, and (b) with 1000 ppm propene.

of $O$ radicals is determined only by the energy density input to the plasma.

At high temperatures, the efficiency for conversion of NO to $\mathrm{NO}_{2}$ is poor in the absence of hydrocarbons in the gas stream. Figure 2(b) shows the $\mathrm{NO}_{x}$ concentrations when $1000 \mathrm{ppm}$ of propene is added to this gas stream. The main fate of NO in the plasma in the presence of hydrocarbons is the oxidation of $\mathrm{NO}$ to $\mathrm{NO}_{2}$.

In the absence of hydrocarbons, the number of NO molecules oxidized to $\mathrm{NO}_{2}$ is determined by the number 
of $\mathrm{O}$ radicals, which is proportional to the energy density input to the plasma. Backconversion of $\mathrm{NO}_{2}$ to $\mathrm{NO}$ by the $O$ radical via reaction (8) decreases the oxidation efficiency. In the presence of hydrocarbons, the radical responsible for the oxidation of $\mathrm{NO}$ to $\mathrm{NO}_{2}$ is no longer the $O$ radical. It will be shown in the following chemical kinetics analysis that the $\mathrm{HO}_{2}$ is the radical that oxidizes $\mathrm{NO}$ to $\mathrm{NO}_{2}$ when the plasma processing is done in the presence of hydrocarbons. The number of $\mathrm{HO}_{2}$ radicals produced in the plasma is a function of both the energy density input to the plasma and the hydrocarbon concentration in the gas stream.

The experiments were interpreted with a detailed chemical kinetics model for propene oxidation [33-35] which included reactions to treat the plasma [23] and $\mathrm{NO}_{\mathrm{x}}$ kinetics. Thermodynamic properties for the relevant radicals and stable parents were obtained by group additivity using THERM [36] with updated $\mathrm{H} / \mathrm{C} / \mathrm{O}$ groups and bond dissociation groups [37]. The thermochemical data allow accurate calculation of reverse reaction rate constants by microscopic reversibility. The $\mathrm{C}_{3}$ mechanism was updated in a number of ways. The reactions involving propane were updated from Ref. [38]. The $\mathrm{NO}_{\mathrm{X}}$ submechanism from GRI Mech ${ }^{\mathrm{TM}}$ [39] has been added to the $\mathrm{C}_{3}$ mechanism. Most of the reaction rate constants were taken from Refs. [40] and [41].

In the very early stages of reaction the propene is mainly consumed by the $\mathrm{O}$ atom:

$$
\begin{aligned}
& \mathrm{C}_{3} \mathrm{H}_{6}+\mathrm{O} \rightarrow \mathrm{C}_{2} \mathrm{H}_{5}+\mathrm{HCO} \\
& \mathrm{C}_{3} \mathrm{H}_{6}+\mathrm{O} \rightarrow \mathrm{CH}_{2} \mathrm{CO}+\mathrm{CH}_{3}+\mathrm{H} \\
& \mathrm{C}_{3} \mathrm{H}_{6}+\mathrm{O} \rightarrow \mathrm{CH}_{3} \mathrm{CHCO}+\mathrm{H}+\mathrm{H}
\end{aligned}
$$

Abstraction reactions by $\mathrm{O}$ atoms do not contribute significantly to propene consumption at the low temperatures encountered in this study because of the higher activation energy of abstraction reactions compared to addition reactions.

Of the total reaction with $\mathrm{O}$ atom, reaction (9) contributes $50 \%$, and reactions (10) and (11) contribute $25 \%$ each. The $O$ atoms are consumed more effectively by reactions (9)-(11) than reactions (4) and (5): $\mathrm{O}+\mathrm{NO} \rightarrow$ $\mathrm{NO}_{2}$.

At $300^{\circ} \mathrm{C}$ and early in the reaction, about $98 \%$ of the $\mathrm{O}$ atoms react with propene compared to $2 \%$ with NO. The rate constants for propene $+\mathrm{O}$ are much faster than that for $\mathrm{NO}+\mathrm{O}$. This result means that the propene consumes most of the $\mathrm{O}$ atoms that might otherwise react with $\mathrm{NO}$ to form $\mathrm{NO}_{2}$.

After the initial stages of reaction, the $\mathrm{OH}$ radical rather than $O$ atom becomes the main radical consuming propene:

$$
\begin{aligned}
& \mathrm{C}_{3} \mathrm{H}_{6}+\mathrm{OH} \rightarrow \mathrm{C}_{3} \mathrm{H}_{6} \mathrm{OH} \\
& \mathrm{C}_{3} \mathrm{H}_{6}+\mathrm{OH} \rightarrow \mathrm{C}_{3} \mathrm{H}_{5}+\mathrm{H}_{2} \mathrm{O}
\end{aligned}
$$

where the $\mathrm{C}_{3} \mathrm{H}_{5}$ radical symbolizes all three isomers, which were distinguished individually in the reaction mechanism. The switch from $\mathrm{O}$ atom reactions to $\mathrm{OH}$ reactions is mainly due to $\mathrm{OH}$ being produced by the reaction

$$
\mathrm{NO}+\mathrm{HO}_{2} \rightarrow \mathrm{NO}_{2}+\mathrm{OH}
$$

Reaction (14) is also the main reaction that converts NO to $\mathrm{NO}_{2}$.

In the presence of $\mathrm{H}_{2} \mathrm{O}$, electron-impact dissociation of $\mathrm{H}_{2} \mathrm{O}$ would produce additional $\mathrm{OH}$ radicals. The metastable oxygen atom, $\mathrm{O}\left({ }^{1} \mathrm{D}\right)$, will react with $\mathrm{H}_{2} \mathrm{O}$ to also produce $\mathrm{OH}$ radicals via reaction (6). These $\mathrm{OH}$ radicals will decompose the hydrocarbons, for example via reactions (12) and (13), and produce hydrocarbon radicals that convert $\mathrm{NO}$ to $\mathrm{NO}_{2}$ in the presence of $\mathrm{O}_{2}$.

The $\mathrm{HO}_{2}$ radicals are also produced from reactions involving hydrocarbon intermediates of propene oxidation:

$$
\begin{aligned}
& \mathrm{CH}_{2} \mathrm{OH}+\mathrm{O}_{2} \rightarrow \mathrm{CH}_{2} \mathrm{O}+\mathrm{HO}_{2} \\
& \mathrm{CH}_{3} \mathrm{O}+\mathrm{O}_{2} \rightarrow \mathrm{CH}_{2} \mathrm{O}+\mathrm{HO}_{2} \\
& \mathrm{HCO}+\mathrm{O}_{2} \rightarrow \mathrm{CO}+\mathrm{HO}_{2} \\
& \mathrm{H}+\mathrm{O}_{2} \rightarrow \mathrm{HO}_{2}
\end{aligned}
$$

Therefore, the propene supplies $\mathrm{HO}_{2}$ radicals that convert $\mathrm{NO}$ to $\mathrm{NO}_{2}$. Without the propene, the main reaction to convert $\mathrm{NO}$ to $\mathrm{NO}_{2}$ are reactions (4) and (5): $\mathrm{O}+\mathrm{NO} \rightarrow \mathrm{NO}_{2}$. Radical-radical reactions involving $\mathrm{O}$ and $\mathrm{OH}$ (such as $\mathrm{OH}+\mathrm{O} \rightarrow \mathrm{HO}_{2}$ ) are not important because of the low concentrations of these radicals.

Nearly all the $O$ atoms for conversion are supplied by electron impact, which has an associated cost in electrical energy. The propene lowers the energy requirement by production of $\mathrm{HO}_{2}$ radicals that then become the main radical for conversion of $\mathrm{NO}$ to $\mathrm{NO}_{2}$.

The $\mathrm{OH}$ produced from reaction (6) can also react with $\mathrm{NO}$ and $\mathrm{NO}_{2}$ to form their related acids:

$$
\begin{aligned}
& \mathrm{NO}+\mathrm{OH} \rightarrow \mathrm{HONO} \\
& \mathrm{NO}_{2}+\mathrm{OH} \rightarrow \mathrm{HONO}_{2}
\end{aligned}
$$

At $300^{\circ} \mathrm{C}$, during the time when the propene is being consumed most rapidly, only about $6 \%$ of the $\mathrm{OH}$ react with $\mathrm{NO}$ and $\mathrm{NO}_{2}$ while the remainder react mostly with propene and its aldehydic intermediate products. At 
$100^{\circ} \mathrm{C}, 15 \%$ of the $\mathrm{OH}$ react with $\mathrm{NO}$ and $\mathrm{NO}_{2}$, while the remainder react mostly with propene and aldehydic intermediates. The rate constants for the $\mathrm{NO}_{x}+\mathrm{OH}$ reactions are much slower than for propene $+\mathrm{OH}$ reactions, so that $\mathrm{OH}$ reacts mainly with propene rather than $\mathrm{NO}$ and $\mathrm{NO}_{2}$ [42].

Because the $\mathrm{OH}$ radical reacts preferentially with the hydrocarbon, the oxidation of $\mathrm{NO}_{2}$ to nitric acid is minimized. If $\mathrm{SO}_{2}$ is present in the exhaust, scavenging of the $\mathrm{O}$ and $\mathrm{OH}$ radicals by the hydrocarbons will also minimize the oxidation of $\mathrm{SO}_{2}$ to $\mathrm{SO}_{3}$. Experimental data demonstrating how hydrocarbons prevent the oxidation of $\mathrm{SO}_{2}$ to $\mathrm{SO}_{3}$ will be shown in another paper.

The hydrocarbon serves important roles not only on the catalyst, but also in the plasma. For lean-burn gasoline engine exhausts, the hydrocarbons are already present mostly in the form of propene - typically at $C_{1}$ concentrations about six times that of NO. For diesel exhausts, the emitted gaseous hydrocarbon levels are much lower; however, the volatile organic fraction of the particulates could be a useful source of additional hydrocarbons.

The hydrocarbons play three important functions in the plasma: (1) the hydrocarbons lower the energy cost for oxidation of $\mathrm{NO}$ to $\mathrm{NO}_{2}$, (2) the hydrocarbons minimize the formation of acid products, and (3) the hydrocarbons prevent the oxidation of $\mathrm{SO}_{2}$ to $\mathrm{SO}_{3}$.

Figure 3 shows the efficiency for plasma oxidation of $\mathrm{NO}$ to $\mathrm{NO}_{2}$ in a model exhaust gas consisting of $500 \mathrm{ppm}$ $\mathrm{NO}, 1000 \mathrm{ppm} \mathrm{C}_{3} \mathrm{H}_{6}, 10 \% \mathrm{O}_{2}$ and balance $\mathrm{N}_{2}$. The plasma oxidation of $\mathrm{NO}$ in the presence of hydrocarbons can have high efficiency over a wide range of temperatures. In comparison, catalytic oxidation of NO to $\mathrm{NO}_{2}$, e.g. using a Pt-based catalyst, can be accomplished only over a much narrower range of temperature.

\section{PLASMA-ASSISTED CATALYSIS}

PROCESS - The plasma-assisted catalytic reduction of $\mathrm{NO}_{\mathrm{X}}$ is accomplished in essentially two steps. First, the plasma oxidizes $\mathrm{NO}$ to $\mathrm{NO}_{2}$ in the presence of a hydrocarbon:

$$
\text { plasma }+\mathrm{NO}+\mathrm{HC}+\mathrm{O}_{2} \rightarrow \mathrm{NO}_{2}+\mathrm{HC} \text {-products }
$$

where $\mathrm{HC}$ refers to a hydrocarbon and HC-products refers to partially oxidized hydrocarbons. Second, the catalyst reduces $\mathrm{NO}_{2}$ to $\mathrm{N}_{2}$ by selective reduction using the hydrocarbons:

$$
\text { catalyst }+\mathrm{NO}_{2}+\mathrm{HC} \rightarrow \mathrm{N}_{2}+\mathrm{CO}_{2}+\mathrm{H}_{2} \mathrm{O} .
$$

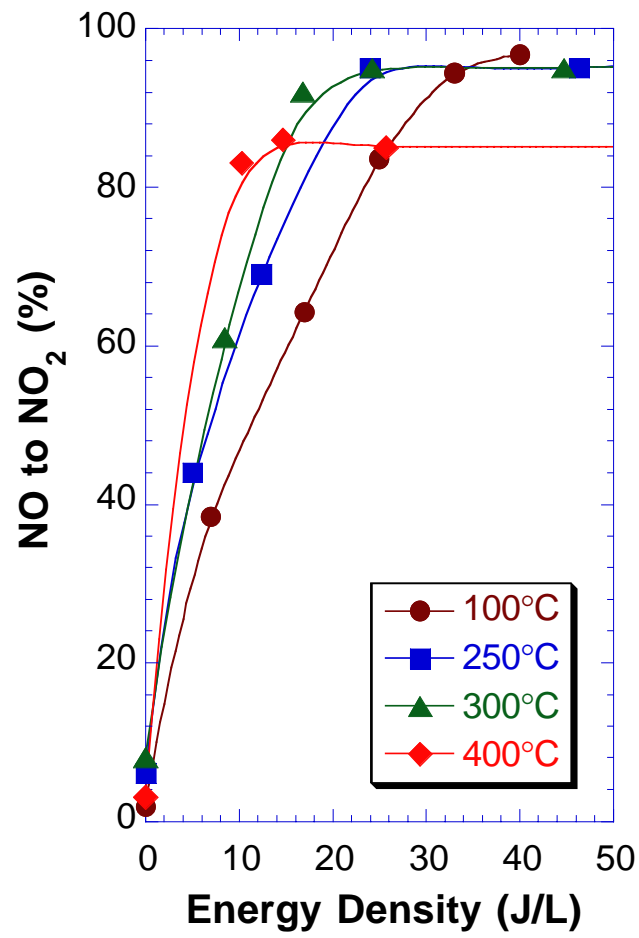

Figure 3. Oxidation of $\mathrm{NO}$ to $\mathrm{NO}_{2}$ in a plasma. Gas mixture: $500 \mathrm{ppm} \mathrm{NO}, 1000 \mathrm{ppm} \mathrm{C}_{3} \mathrm{H}_{6}, 10 \% \mathrm{O}_{2}$, balance $\mathrm{N}_{2}$.

There are three key features in the plasma-assisted catalytic reduction of $\mathrm{NO}_{\mathrm{x}}$.

- First, the plasma oxidation process is partial. This means the plasma oxidizes $\mathrm{NO}$ to $\mathrm{NO}_{2}$ but does not further oxidize $\mathrm{NO}_{2}$ to nitric acid. The plasma also produces some partially oxygenated hydrocarbons, but does not completely oxidize the hydrocarbons to $\mathrm{CO}_{2}$ and $\mathrm{H}_{2} \mathrm{O}$. For some catalysts, the partially oxygenated hydrocarbons are much more effective compared to the original hydrocarbons in reducing $\mathrm{NO}_{x}$ to $\mathrm{N}_{2}$.

- Second, the plasma oxidation process is selective. This means the plasma oxidizes $\mathrm{NO}$ to $\mathrm{NO}_{2}$, but does not oxidize $\mathrm{SO}_{2}$ to $\mathrm{SO}_{3}$. This makes the plasma-assisted process more tolerant to the sulfur content of fuel compared to conventional lean- $\mathrm{NO}_{\mathrm{X}}$ technologies.

- Third, by using a plasma to change the composition of $\mathrm{NO}_{x}$ from $\mathrm{NO}$ to $\mathrm{NO}_{2}$, one can take advantage of a new class of catalysts that are potentially more durable and more active than conventional lean $-\mathrm{NO}_{\mathrm{x}}$ catalysts.

TEST SETUP - Figure 4 shows one of the possible embodiments of the plasma-assisted catalyst processor. In this setup the plasma reactor is located upstream of 
the catalyst reactor. The same result is achieved if the catalyst is placed inside the plasma reactor.

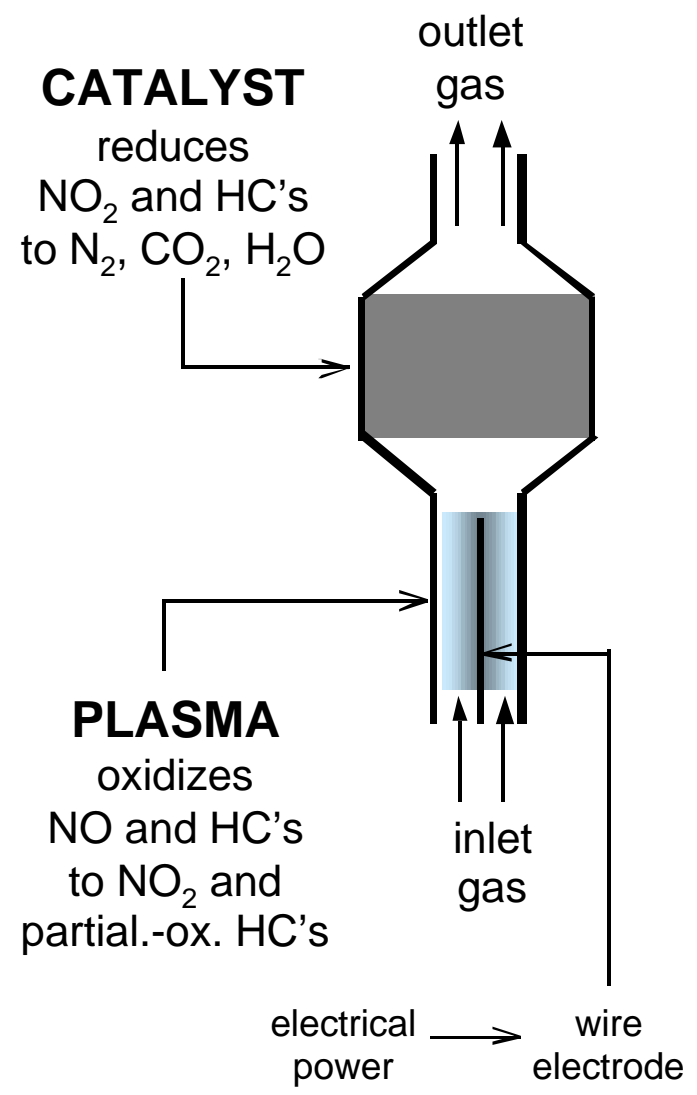

Figure 4. An embodiment of the plasma-assisted catalytic reduction process. The same result is achieved if the catalyst is placed inside the plasma reactor.

The separate plasma/catalyst configuration shown in Figure 4 is very flexible. Although we have used a pulsed corona reactor, this type of reactor is not necessarily the only type that produces the same effect. It can be used with any type of plasma reactor and does not require a specific type of high-voltage power supply. All electrical discharge plasma reactors accomplish essentially the same gas-phase plasma chemistry for the same gas mixture [26-28].

The separate plasma/catalyst configuration is also very flexible with respect to the catalyst support structure. It can be used with a bed of catalyst pellets or a monolith. For monolith structures, any L/D (length/diameter) ratio can be accommodated.

Tests of the plasma/catalyst processor have been done using both a simulated exhaust gas mixture and a real exhaust from a Cummins B5.9 diesel engine.

CATALYST - The aim of this paper is to demonstrate the improvement in $\mathrm{NO}_{X}$ reduction efficiency that can be accomplished by combining an SCR catalyst with a plasma. For this purpose we have chosen $\gamma-\mathrm{Al}_{2} \mathrm{O}_{3}$ as a representative SCR catalyst for three reasons. First, many groups have shown that $\gamma-\mathrm{Al}_{2} \mathrm{O}_{3}$ is much more active as an SCR catalyst for the reduction of $\mathrm{NO}_{2}$ compared to $\mathrm{NO}[3,43-47] . \gamma-\mathrm{Al}_{2} \mathrm{O}_{3}$ is one of the best non-proprietary materials for taking advantage of the presence of $\mathrm{NO}_{2}$. Second, several studies [48-49] comparing a wide variety of SCR catalysts, including zeolites and metal oxides, have found $\gamma-\mathrm{Al}_{2} \mathrm{O}_{3}$ to be one of the most active for $\mathrm{NO}_{X}$ reduction by hydrocarbons. Third, $\gamma-\mathrm{Al}_{2} \mathrm{O}_{3}$ can be prepared in a hydrothermally stable form, thus making it a suitable catalyst or catalyst support for a practical device. Studies using a real diesel engine exhaust have shown that $\gamma-\mathrm{Al}_{2} \mathrm{O}_{3}$ retains its $\mathrm{NO}_{x}$ reduction activity over a long period of time [50].

In plasma-assisted catalysis, the $\mathrm{NO}_{\mathrm{X}}$ to $\mathrm{N}_{2}$ conversion is determined by the catalyst. Catalyst characterization has been done using a $\mathrm{He}$ background gas to establish real conversion of $\mathrm{NO}_{x}$ to $\mathrm{N}_{2}$.

Combining a plasma with $\gamma-\mathrm{Al}_{2} \mathrm{O}_{3}$ can provide $\mathrm{NO}_{x}$ reduction efficiencies much higher than those achieved by the conventional approach of loading a metal on $\gamma$ $\mathrm{Al}_{2} \mathrm{O}_{3}$. Figure $5(\mathrm{a})$ shows the $\mathrm{NO}$ reduction to $\mathrm{N}_{2}$ for $\gamma$ $\mathrm{Al}_{2} \mathrm{O}_{3}$. The temperature operating window occurs at a

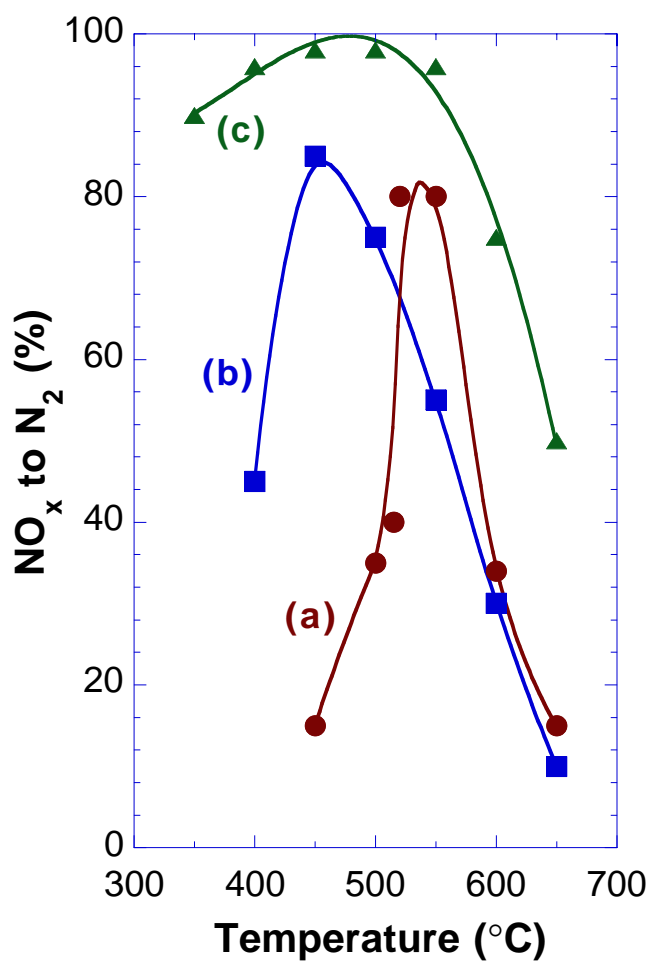

Figure 5. $\mathrm{NO}_{\mathrm{x}}$ reduction to $\mathrm{N}_{2}$ as a function of temperature. (a) $\mathrm{NO}$ over $\gamma-\mathrm{Al}_{2} \mathrm{O}_{3}$, (b) $\mathrm{NO}$ or $\mathrm{NO}_{2}$ over 2 wt $\% \mathrm{Ag} / \mathrm{Al}_{2} \mathrm{O}_{3}$, (c) $\mathrm{NO}_{2}$ over $\gamma-\mathrm{Al}_{2} \mathrm{O}_{3}$. Catalyst weight, $0.25 \mathrm{~g}$. Dry gas feed, $1000 \mathrm{ppm} \mathrm{NO}$ or $\mathrm{NO}_{2}, 1000$ ppm $\mathrm{C}_{3} \mathrm{H}_{6}, 6 \% \mathrm{O}_{2}$, balance $\mathrm{He}$ at $100 \mathrm{~mL} / \mathrm{min}$. Space velocity $=12,000 / \mathrm{hr}$. Data taken from Ref. [46]. 
high temperature and is narrow. The addition of $2 \mathrm{wt} \%$ $\mathrm{Ag}$ to $\gamma-\mathrm{Al}_{2} \mathrm{O}_{3}$ increases the NO reduction in the lower temperature region, as shown in Figure $5(\mathrm{~b})$. When the input gas feed contains $\mathrm{NO}_{2}$ instead of $\mathrm{NO}$, the $\mathrm{NO}_{\mathrm{x}}$ reduction activity over $\gamma-\mathrm{Al}_{2} \mathrm{O}_{3}$ increases dramatically over a wide range of temperature, as shown in Figure 5(c).

Figure 6(a) shows the NO reduction to $\mathrm{N}_{2}$ for 2 wt\% $\mathrm{Co} / \mathrm{Al}_{2} \mathrm{O}_{3}$. With the same catalyst, the reduction activity in the lower temperature region is increased when the input gas feed contains $\mathrm{NO}_{2}$ instead of $\mathrm{NO}$, as shown in Figure 6(b). However, when $\mathrm{NO}_{2}$ is used with pure $\gamma$ $\mathrm{Al}_{2} \mathrm{O}_{3}$, the $\mathrm{NO}_{\mathrm{x}}$ reduction activity is higher over a much wider range of temperature, as shown in Figure 6(c).

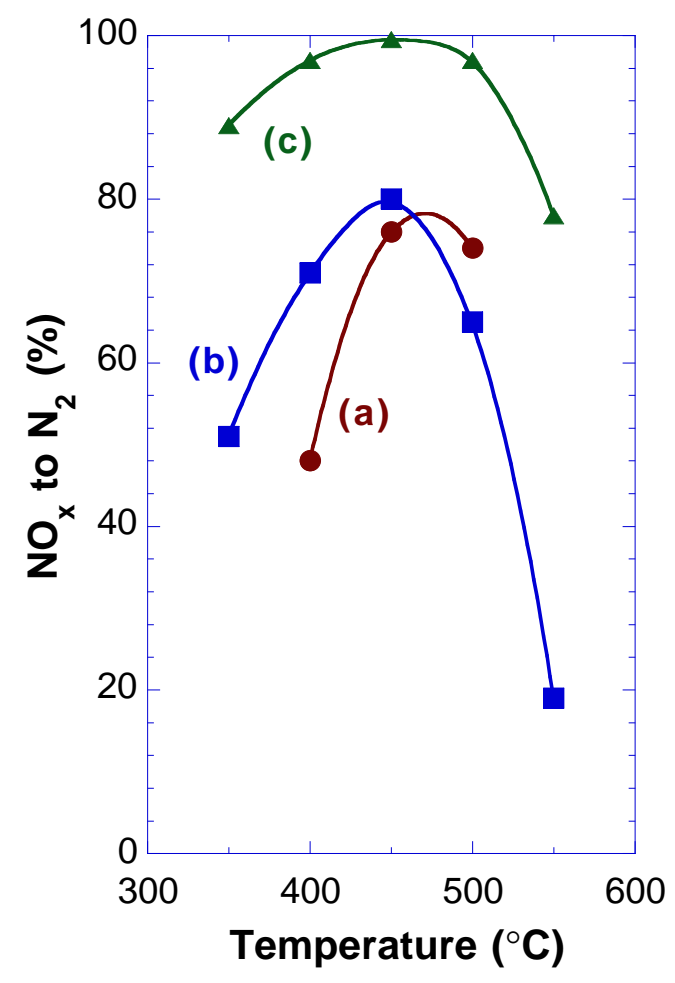

Figure 6. $\mathrm{NO}_{\mathrm{x}}$ reduction to $\mathrm{N}_{2}$ as a function of temperature. (a) $\mathrm{NO}$ over 2 wt\% $\mathrm{Co} / \mathrm{Al}_{2} \mathrm{O}_{3}$, (b) $\mathrm{NO}_{2}$ over $2 \mathrm{wt} \% \mathrm{Co} / \mathrm{Al}_{2} \mathrm{O}_{3}$, (c) $\mathrm{NO}_{2}$ over $\gamma-\mathrm{Al}_{2} \mathrm{O}_{3}$. Catalyst weight, $0.25 \mathrm{~g}$. Dry gas feed, $1000 \mathrm{ppm} \mathrm{NO}$ or $\mathrm{NO}_{2}, 1000 \mathrm{ppm}$ $\mathrm{C}_{3} \mathrm{H}_{6}, 5 \% \mathrm{O}_{2}$, balance $\mathrm{He}$ at $100 \mathrm{~mL} / \mathrm{min}$. Space velocity $=12,000 / \mathrm{hr}$. Data taken from Ref. [47].

Figure 7 shows the $\mathrm{NO}_{x}$ reduction to $\mathrm{N}_{2}$ over a monolith washcoated with $\gamma-\mathrm{Al}_{2} \mathrm{O}_{3}$. The $\mathrm{NO}_{x}$ reduction is much higher when the input $\mathrm{NO}_{x}$ is $\mathrm{NO}_{2}$ instead of $\mathrm{NO}$.

Figures 5-7 illustrate how the conversion of $\mathrm{NO}$ to $\mathrm{NO}_{2}$ can significantly increase the SCR activity. The gas feeds used were dry. It is known that $\mathrm{H}_{2} \mathrm{O}$ degrades the SCR activity of $\gamma-\mathrm{Al}_{2} \mathrm{O}_{3}$. The negative effect of $\mathrm{H}_{2} \mathrm{O}$ on the SCR activity of various catalysts, and how the effect can be overcome, is an important topic that is outside the scope of this paper. In the next section we will show the SCR activity of $\gamma-\mathrm{Al}_{2} \mathrm{O}_{3}$ for a real diesel engine exhaust, which contains about $5 \% \mathrm{H}_{2} \mathrm{O}$.

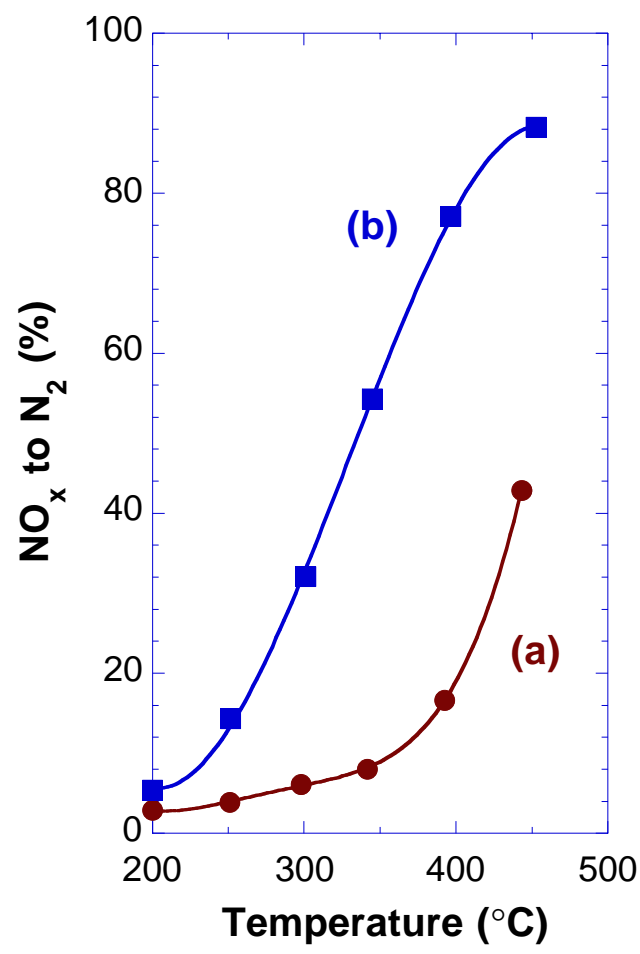

Figure 7. Selective catalytic reduction of $\mathrm{NO}_{\mathrm{x}}$ over a monolith washcoated with $\gamma-\mathrm{Al}_{2} \mathrm{O}_{3}$. Space velocity $=$ $18,000 / \mathrm{hr}$. L/D $=3$. Dry gas feed. Gas mixture: 1000 ppm $\mathrm{C}_{3} \mathrm{H}_{6}, 10 \% \mathrm{O}_{2}$, balance $\mathrm{N}_{2}$. (a) Input $\mathrm{NO}_{\mathrm{x}}$ consisting of 500 ppm NO, (b) Input $\mathrm{NO}_{\mathrm{X}}$ consisting of $500 \mathrm{ppm} \mathrm{NO}$.

DIESEL ENGINE EXHAUST DATA - Figure 8 shows data on plasma-assisted catalytic reduction of $\mathrm{NO}_{X}$ using a slipstream of the exhaust from a Cummins B5.9 diesel engine. The reactor used in this run consisted of a pulsed corona plasma reactor packed with $\gamma-\mathrm{Al}_{2} \mathrm{O}_{3}$ pellets. The total plasma + catalyst reactor volume was $0.5 \mathrm{~L}$. A Cummins B5.9 diesel engine running with a 95 $\mathrm{kW}$ load was used as the source of $\mathrm{NO}_{\mathrm{X}}$. The engine-out $\mathrm{NO}_{\mathrm{x}}$ was $600 \mathrm{ppm}$. The exhaust temperature was typically between $350-400^{\circ} \mathrm{C}$ when the engine load is $95 \mathrm{~kW}$. The temperature of the plasma/catalyst reactor was set at $370^{\circ} \mathrm{C}$. Propene was used as the hydrocarbon reductant, with a $\mathrm{C}_{1} / \mathrm{NO}_{\mathrm{x}}$ ratio of 5 . Figure 8 shows the amount of $\mathrm{NO}_{x}$ reduction at space velocities of 12,000 and $18,000 / \mathrm{hr}$. The $\mathrm{NO}_{\mathrm{x}}$ reduction increases dramatically as the energy density delivered to the plasma is increased.

We have chosen $\gamma-\mathrm{Al}_{2} \mathrm{O}_{3}$ as a representative SCR catalyst that works very well in combination with a 
plasma. However, it is not necessarily the best catalyst for this purpose.

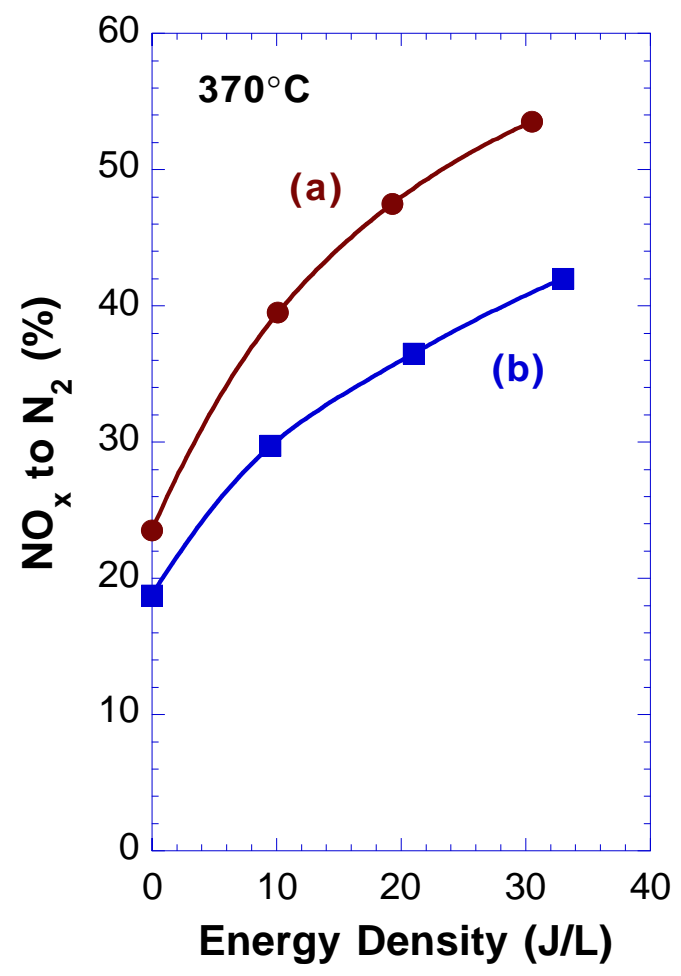

Figure 8. Plasma-assisted catalytic reduction of $\mathrm{NO}_{\mathrm{x}}$ at $370^{\circ} \mathrm{C}$ in a pulsed corona plasma reactor packed with $\gamma-\mathrm{Al}_{2} \mathrm{O}_{3}$ pellets. Total plasma+catalyst reactor volume $=$ $0.5 \mathrm{~L}$. The $\mathrm{NO}_{\mathrm{X}}$ reduction is shown as a function of the energy density input to the plasma. A Cummins B5.9 diesel engine running with a $95 \mathrm{~kW}$ load was used as the source of $\mathrm{NO}_{\mathrm{X}}$. Propene reductant $\mathrm{C}_{1} / \mathrm{NO}_{\mathrm{X}}=5$. Space velocity: (a) $12,000 / \mathrm{hr}$, and (b) 18,000 /hr.

Actual exhaust from a diesel engine contains around $10 \% \mathrm{CO}_{2}$ and $5 \%$ or more $\mathrm{H}_{2} \mathrm{O}$, in addition to the $10 \%$ $\mathrm{O}_{2}$. The $\mathrm{H}_{2} \mathrm{O}$ component is known to decrease the SCR efficiency of $\gamma-\mathrm{Al}_{2} \mathrm{O}_{3}$. Some studies suggest that it is possible to overcome the detrimental effect of $\mathrm{H}_{2} \mathrm{O}$ on SCR activity. For example, Maunala et al. [18] have observed that the activity of $\mathrm{In} / \mathrm{Al}_{2} \mathrm{O}_{3}$ remains high even in the presence of $\mathrm{H}_{2} \mathrm{O}$ when the input $\mathrm{NO}_{x}$ is $\mathrm{NO}_{2}$.

\section{CONCLUSIONS}

The oxidation of $\mathrm{NO}$ to $\mathrm{NO}_{2}$ serves an important role in enhancing the efficiency for SCR of $\mathrm{NO}_{x}$ to $\mathrm{N}_{2}$. A nonthermal plasma is a very effective means for oxidizing $\mathrm{NO}$ to $\mathrm{NO}_{2}$ in the gas-phase under lean-burn engine exhaust conditions. When combined with some types of SCR catalyst, the plasma can greatly enhance the $\mathrm{NO}_{x}$ reduction and eliminate some of the deficiencies encountered in an entirely catalyst-based approach. The plasma can efficiently oxidize $\mathrm{NO}$ to $\mathrm{NO}_{2}$ over a wide range of temperature without depleting the amount of hydrocarbons available for SCR of $\mathrm{NO}_{2}$ to $\mathrm{N}_{2}$. Furthermore, in the presence of hydrocarbons the plasma can oxidize $\mathrm{NO}$ without oxidizing $\mathrm{SO}_{2}$, thus making the process tolerant to the sulfur content of the fuel. Experimental data demonstrating the sulfur tolerance of the hydrocarbon-enhanced plasma oxidation process will be shown in another paper.

\section{ACKNOWLEDGMENTS}

The work at Lawrence Livermore National Laboratory was performed under the auspices of the U.S. Department of Energy under Contract Number W-7405ENG-48, with support from the Chemical Sciences Division of the DOE Office of Basic Energy Sciences, the DOE Office of Fossil Energy, the Strategic Environmental Research and Development Program, and a Cooperative Research and Development Agreement with Cummins Engine Company. The work at Northwestern University was supported by the Chemical Sciences Division of the DOE Office of Basic Energy Sciences.

\section{REFERENCES}

1. Shelef, M., "Selective Catalytic Reduction of $\mathrm{NO}_{\mathrm{x}}$ With N-Free Reductants", Chem. Rev. 95, 209 (1995).

2. Tabata, T., Kokitsu, M., and Okada, O., "Study on Patent Literature of Catalysts for a New $\mathrm{NO}_{x}$ Removal Process", Catal. Today 22, 147 (1994).

3. Hamada, H., Kintaichi, Y., Sasaki, M., Ito, T., and Tabata, M., "Selective Reduction of Nitrogen Monoxide with Propane over Alumina and HZSM-5 Zeolite - Effect of Oxygen and Nitrogen Dioxide Intermediate", Appl. Catal. 70, L15 (1991).

4. Petunchi, J.O. and Hall, W.K., "On the Role of Nitrogen Dioxide in the Mechanism of the Selective Reduction of $\mathrm{NO}_{\mathrm{x}}$ over Cu-ZSM-5 Zeolite", Appl. Catal. B: Environmental 2, L17 (1993).

5. Petunchi, J.O., Sill, G., and Hall, W.K., "Studies of the Selective Reduction of Nitric Oxide by Hydrocarbons", Appl. Catal. B: Environmental 2, 303 (1993).

6. Valyon, J. and Hall, W.K., "Studies of the Surface Species Formed from NO on Copper Zeolites" J. Phys. Chem. 97, 1204 (1993).

7. Sasaki, M., Hamada, H., Kintaichi, Y., and Ito, T., "Role of Oxygen in Selective Reduction of Nitrogen Monoxide by Propane over Zeolite and AluminaBased Catalysts" Catal. Lett. 15, 297 (1992). 
8. Shelef, M., Montreuil, C.N., and Jen, H.W., " $\mathrm{NO}_{2}$ Formation Over Cu-ZSM-5 and the Selective Catalytic Reduction of NO", Catal. Lett. 26, 277 (1994).

9. Yokoyama, C. and Misono, M., "Catalytic Reduction of Nitrogen Oxides by Propene in the Presence of Oxygen over Cerium Ion-Exchanged Zeolites: 2. Mechanistic Study of Roles of Oxygen and Doped Metals", J.Catal. 150, 9 (1994).

10. Bamwenda, G.R., Ogata, A., Obuchi, A., Takahashi, $\mathrm{H}$., and Mizuno, K., "Selective Reduction of $\mathrm{NO}_{2}$ by Propylene in Excess Oxygen Over $\mathrm{Rh} / \mathrm{Al}_{2} \mathrm{O}_{3}$. Drift Spectroscopy and Activity Studies", React. Kinet. Catal. Lett. 56, 311 (1995).

11. Lukyanov, D.B., Sill, G., Ditri, J.L., and Hall, W.K., "Comparison of Catalyzed and Homogeneous Reactions of Hydrocarbons for Selective Catalytic Reduction (SCR) of NO X", J.Catal. 153, 265 (1995).

12. Beutel, T., Adelman, B.J., Lei, G.D., and Sachtler, W.M.H., "Potential Reaction Intermediates of $\mathrm{NO}_{\mathrm{X}}$ Reduction with Propane over Cu/ZSM-5", Catal. Lett. 32, 83 (1995).

13. Ansell, G.P., Diwell, A.F., Golunski, S.E., Hayes, J.W., Rajaram, R.R., Truex, T.J., and Walker, A.P., "Mechanism of the Lean NOx Reaction over Cu/ZSM-5" Appl. Catal. B 2, 81 (1993).

14. Kung, M., Bethke, K., Alt, D., Yang, B. and Kung, H., in NOx Reduction, ACS Symposium Series (1995).

15. Shimokawabe, M., Ohi, A., and Takezawa, N., "Catalytic Reduction of Nitrogen Dioxide with Propene in the Presence and Absence of Oxygen Over Various Metal Oxides", React. Kinet. Catal. Lett. 52, 393 (1994).

16. Hirao, Y., Yokoyama, C., and Misono, M., "Enhancement by Water Vapour of Catalytic Reduction of NO by Propene Over Mechanically Mixed $\mathrm{Mn}_{2} \mathrm{O}_{3}$ and Sn-ZSM-5", Chem. Comm. March 7, 597 (1996).

17. Misono, M., Hirao, Y., and Yokoyama, C., "Reduction of Nitrogen Oxides with Hydrocarbons Catalyzed by Bifunctional Catalysts", Catal. Today 38, 157 (1997).

18. Maunala, T., Kintaichi, Y., Inaba, M., Haneda, M., Sato, K, and Hamada, H., "Enhanced Activity of In and Ga-Supported Sol-Gel Alumina Catalysts for NO Reduction by Hydrocarbons in Lean Conditions", Appl. Catal. B: Environmental 15, 291 (1998).
19. Iwamoto, M., Hernandez, A.M., and Zengyo, T., "Oxidation of $\mathrm{NO}$ to $\mathrm{NO}_{2}$ on a Pt-MFI Zeolite and Subsequent Reduction of $\mathrm{NO}_{\mathrm{x}}$ by $\mathrm{C}_{2} \mathrm{H}_{4}$ on an InMFI Zeolite: a Novel De-NO $\mathrm{N}_{x}$ Strategy in Excess Oxygen", Chem. Comm. Jan 7, 37 (1997).

20. Iwamoto, M. and Zengyo, T., "Highly Selective Reduction of $\mathrm{NO}$ in Excess Oxygen through the Intermediate Addition of Reductant (IAR) Between Pt- and Zn-MFI Zeolites", Chem. Lett. 1283 (1997).

21. Bethke, K.A., Li, C., Kung, M.C., Yang, B., et al., "The Role of $\mathrm{NO}_{2}$ in the Reduction of $\mathrm{NO}$ by Hydrocarbon over $\mathrm{Cu}-\mathrm{ZrO}_{2}$ and $\mathrm{Cu}-\mathrm{ZSM}-5$ Catalysts", Catal. Lett. 31, 287 (1995).

22. Chajar, Z., Primet, M., Praliaud, H., Chevrier, M., Gauthier, C., and Mathis, F., "Nitrogen Dioxide Effect in the Reduction of Nitric Oxide by Propane in Oxidizing Atmosphere", Catal. Lett. 28, 33 (1994).

23. Penetrante, B.M., in "Non-Thermal Plasma Techniques for Pollution Control - Part A: Overview, Fundamentals and Supporting Technologies" (B.M. Penetrante and S.E. Schultheis, Eds.), p. 65. Springer-Verlag, Berlin Heidelberg New York, 1993.

24. Penetrante, B.M., Bardsley, J.N., and Hsiao, M.C., "Kinetic Analysis of Non-Thermal Plasmas Used for Pollution Control", Jap. J. Appl. Phys. 3 6, 5007 (1997).

25. Penetrante, B.M., Hsiao, M.C., Bardsley, J.N., Merritt, B.T., Vogtlin, G.E., Kuthi, A., Burkhart, C.P., and Bayless, J.R., "Identification of Mechanisms for Decomposition of Air Pollutants by Non-Thermal Plasma Processing", Plasma Sources Sci. Tech. 6 , 251 (1997).

26. Penetrante, B.M., Hsiao, M.C., Merritt, B.T., Vogtlin, G.E., Wallman, P.H., Neiger, M., Wolf, O., Hammer, T. and Broer, S., "Pulsed Corona and DielectricBarrier Discharge Processing of $\mathrm{NO}$ in $\mathrm{N}_{2}$ ", Appl. Phys. Lett. 68, 3719 (1996).

27. Penetrante, B.M., Hsiao, M.C., Merritt, B.T., Vogtlin, G.E., Wallman, P.H., Kuthi A., Burkhart, C.P., and Bayless, J.R., "Electron-Impact Dissociation of Molecular Nitrogen in Atmospheric-Pressure NonThermal Plasma Reactors", Appl. Phys. Lett. 67 , 3096 (1995).

28. Penetrante, B.M., Hsiao, M.C., Merritt, B.T., Vogtlin, G.E. and Wallman, P.H., "Comparison of Electrical Discharge Techniques for Non-Thermal Plasma Processing of $\mathrm{NO}$ in $\mathrm{N}_{2}$.", IEEE Trans. Plasma Sci. 23, 679 (1995). 
29. Penetrante, B.M., Hsiao, M.C., Merritt, B.T., and Vogtlin, G.E., "Fundamental Limits on NOx Reduction by Plasma”, SAE Paper 971715 (1997).

30. Zipf, E.C., Espy, P.J. and Boyle, C.F., "The Excitation and Collisional Deactivation of Metastable N(2P) Atoms in Auroras", J. Geophys. Res. 85, 687 (1980).

31. Cosby, P.C., "Electron-impact Dissociation of Nitrogen”, J. Chem. Phys. 98, 9544 (1993).

32. Schofield, K., "Critically Evaluated Rate Constants for Gaseous Reactions of Several Electronically Excited Species", J. Phys. Chem. Ref. Data 8, 723 (1979).

33. Wilk, R.D., Cernansky, N.P., Pitz, W.J. and Westbrook, C.K., "Propene Oxidation at Low and Intermediate Temperatures - A Detailed Chemical Kinetic Study", Combust. Flame 77, 145 (1989).

34. Koert, D.N., Pitz, W.J. and Bozzelli, J.W., "Chemical Kinetic Modeling of High Pressure Propane Oxidation and Comparison to Experimental Results", Twenty-Sixth International Symposium on Combustion, The Combustion Institute, Pittsburgh, PA, 1996, p. 633-640.

35. Pitz, W.J., Westbrook, C.K. and Leppard, W.R., "Autoignition Chemistry of C4 Olefins Under Motored Engine Conditions: A Comparison of Experimental and Modeling Results", SAE Paper 912315 (1991).

36. Ritter, E.R. and Bozzelli, J.W.," THERM Thermodynamic Property Estimation for Gas Phase Radicals and Molecules", Int. J. Chem. Kinet. 23, 767 (1991).

37. Lay, T.H., Bozzelli, J.W., Dean, A.M. and Ritter, E.R., "Hydrogen Atom Bond Increments for Calculation of Thermodynamic Properties of Hydrocarbon Radical Species", J. Phys. Chem. 99, 14514 (1995).

38. Marinov, N.M., Castaldi, M.J., Melius, C.F. and Tsang, W., "Aromatic and Polycyclic Aromatic Hydrocarbon Formation in a Premixed Propane Flame", Comb. Sci. Tech. 28, 295 (1997).

39. Bowman, C.T., Hanson, R.K., Davidson, D.F., Gardiner, Jr., W.C., Lissianski, V., Smith, G.P., Golden, D.M., Frenklach, M. and M. Goldenberg, http://www.me.berkeley.edu/gri_mech, 1997.

40. Atkinson, R., Baulch, D.L., Cox, R.A., Hampson, Jr., R.F., Kerr, J.A. and Troe, J., "Evaluated Kinetic, Photochemical and Heterogeneous Data for
Atmospheric Chemistry", J. Phys. Chem. Ref. Data 26, 521 (1997).

41. Dean, A.M. and Bozzelli, J.W., "Combustion Chemistry of Nitrogen", in Combustion Chemistry II , ed. W. Gardiner, Jr. (Springer-Verlag, New York, 1997).

42. Pitz, W.J., Penetrante, B.M., Hsiao, M.C. and Vogtlin, G.E., "Simultaneous Oxidation of NO and Hydrocarbons in a Non-Thermal Plasma", 1997 Fall Meeting of the Western States Section of the Combustion Institute.

43. Radtke, F., Koeppel, R.A., and Baiker, A., "Harmful By-Products in Selective Catalytic Reduction of Nitrogen Oxides by Olefins over Alumina", Catal. Lett. 28, 131 (1994).

44. Kung, M., Lee, J.-H., Chu-Kung, A., and Kung, H.H., in "Proceedings, 11th International Congress on Catalysis-40th Anniversary" (J.W. Hightower, W.N. Delgass, E. Iglesia, and A.T. Bell, Eds), Vol. 101, p. 701. Elsevier, Amsterdam, 1996.

45. Radtke, F., Koeppel, R.A., Minardi, E.G., and Baiker, A., "Catalytic Reduction of Nitrogen Oxides by Olefins in the Presence of Oxygen over Copper/Alumina: Influence of Copper Loading and Formation of Byproducts", J. Catal. 167, 127 (1997).

46. Bethe, K.A and Kung, H.H., "Supported Ag Catalyst for the Lean Reduction of $\mathrm{NO}$ with $\mathrm{C}_{3} \mathrm{H}_{6}$ ", J. Catal. 172, 93 (1997).

47. Yan, J.-Y., Kung, M.C., Sachtler, W.M.H., and Kung, H.H., "Co/Al ${ }_{2} \mathrm{O}_{3}$ Lean $\mathrm{NO}_{x}$ Reduction Catalyst", $J$. Catal. 172, 178 (1997).

48. Misono, M. and Kondo, K., "Catalytic Removal of Nitrogen Monoxide over Rare-Earth Ion-Exchanged Zeolites in the Presence of Propene and Oxygen", Chem. Lett. June, 1001 (1991).

49. Hamada, H., "Selective Reduction of NO by Hydrocarbons and Oxygenated Hydrocarbons over Metal Oxide Catalysts", Catal. Today 22, 21 (1994).

50. Tabata, M., Tsuchida, H., Miyamoto, K., Yoshinari, T., et al., "Reduction of $\mathrm{NO}_{\mathrm{X}}$ in Diesel Exhaust with Methanol over Alumina Catalyst", Appl. Catal. B: Environmental 6, 169 (1995). 